UDC: $378.091 .2-057.86$

DOI: https://doi.org/10.24195/2414-4665-2017-4-26

Anatolii Solonenko,
Doctor of Biology, associate professor, Department of Botany and Landscape Architecture, rector of Melitopol Bohdan Khmelnytskyi State Pedagogical University,

20, Hetmanska Str., Melitopol, Ukraine,

Olha Poznanska,

Head of the Bureau on the Questions of Special Inspection and Lustration of Government of the Staff Department of Ministry of Education and Science of Ukraine,

10, Peremohy Avenue, Kyiv, Ukraine,

Yulia Popeleshko,

PhD (Candidate of Pedagogical Sciences), senior lecturer, Department of Pedagogy and Pedagogical Mastery, Melitopol Bohdan Khmelnytskyi State Pedagogical University,

20, Hetmanska Str., Melitopol, Ukraine,

\title{
SCIENTIFIC AND METHODOLOGICAL CONTEXT OF THE ISSUE OF TUTORS' PROFESSIONAL TRAINING IN THE HIGHER EDUCATION SYSTEM OF UKRAINE
}

The article reveals the problem of tutors' professional training in the higher education system of Ukraine. According to the plan of research work of scientific-pedagogical project "Tutor School of Excellence" on the basis of Melitopol Bohdan Khmelnytskyi State Pedagogical University the diagnostics of scientific and pedagogical staff readiness for innovation was carried out. 186 people participated in the study who were divided into two experimental groups (EG 1.1 and EG 1.2) and two control groups (CG 1.1 and CG 1.2). The research work consisted of three stages: explorative-theoretical, experimental, and consolidating. In order to determine the readiness for innovative activity of the teaching staff the questionnaires and diagnostic techniques "The methods of determining the teacher's ability to self-development" (by I. Dychkivska), "The map of pedagogical evaluation (selfevaluation) of teacher's ability to innovate activity" (O. Marmaza) were used. The results of the research proved that the system of tutors' training should involve three interconnected blocks: the target, content-operational and resulting ones. The analysis of the results of the formative experiment has shown that in experimental groups, where the purposeful professional training of pedagogues for tutor activity was delivered, the overall index of the level of readiness for this type of activity increased from low to high. In the control groups it has increased from low to medium. In terms of higher education modernization in Ukraine, the creation of conditions for the organization of the innovation process is essential. This requires the training of tutors who will acquire the skills of facilitation and tutor excellence. Thus, in the process of transition of educational institutions into a new qualitative state of functioning, the leading role belongs to the development and implementation of pedagogical innovations, by efforts of professionally competent, psychologically well-prepared, creative teaching staff in collaboration with scientists. Moreover, this process of practice and theory interconnection in pedagogy is inseparable.

Keywords: tutor, tutor activity, pedagogical innovations, training, competence.

\section{Introduction}

Global transformations covering the modern field of education in Ukraine are focused on the implementation of conceptual bases of innovative educational policy which are being formed at the national level. Responding quickly to the demands of the society, higher educational institutions choose innovativeness as a key direction of their activities which, in its turn, predicts flexibility of educational activity and its radical restructuring. The efficiency of innovative educational technologies is considerably responsible not only for the educational system functioning, but for its overall final result. At this, modernization of innovative educational activity becomes a major resource that is expected to optimize the educational sector through the improvement of activities referring to all subjects of the educational process.

Professional training of tutors in higher educational institutions is a mandatory component which increases the level of their professional skills and competence. In the con- tent plane tutor activity should be seen as organizational psycho-pedagogical and social support of senior school and university students' individual education, resulting in the need to develop systematic knowledge, skills, attitudes and beliefs, value orientations and a certain level of cognitive processes and practical training which involves analytical description, characterization, classification and systematization of mechanisms of psycho-pedagogical and social support of tutorial practice; to study the laws and regulations that determine the effectiveness of tutor support; to study the genesis and development of various types of tutorial practices, the main trends of their development. The issue of continuous improvement of the professional activity of tutors as experts able to implement innovation activities in any educational institution is considered to be of particular relevance. Correspondingly, tutors' professional training should be focused on the formation of the person capable of performing professional activity under modern conditions. 
Among the important aspects of the study of tutors' training, they distinguish scientific substantiation of its essence which provides the updating of scientific and methodological support of the educational process, organic integration of science and education, active use of innovative educational technologies for the improvement of the quality of tutors' training.

The modern demands imposed on tutors by the society and the state, require significant changes in their professional training. The content, forms and methods of tutors' training in higher educational institutions are a subject of modernization, and all those have to consider the achievements of modern science and practice in the field of innovation activities. According to the data provided by the Institute of Pedagogy of the National Academy of Pedagogical Sciences of Ukraine, at present the level of teachers' professional training as for the use of educational innovative achievements has been found insufficient. Thus, many teachers study innovative experience of their colleagues, finding something important and interesting for themselves there, or confine themselves to a few guidelines. In many cases, the ability to choose innovative variants depends on tutors' cognitive and search activity, whereas the bases of this activity is their training which involves the introduction of innovative learning technologies.

The development of tutors' professional training in Ukraine is characterized by a large number of scientific and educational research studies. However, not all aspects of the issue have been explored. In this regard, there is a need for the detailed analysis and theoretical justification of scientific and methodological context of tutors' professional training in the higher education system. The works of the following researchers are considered to be significant for the development of theoretical bases of tutors' training: V. Artiomenko, I. Bekh, A. Boiko, R. Vastianov, S. Vetrov, M. Holubeva, O. Honcharova, N. Demianenko, S. Zaikovska, O. Litovka, T. Lytvynenko, V. Nikitin and others.

The paper aims to determine the scientific and methodological context of tutors' professional training in the higher educational system of Ukraine.

\section{Discussion}

The current state of Ukraine's development is characterized by fundamental content and organizational changes aimed at reforming the national education system. The main component of education reforming is considered to be updating the content and structure of activities performed by higher educational institutions in Ukraine. The scientific literature analysis gives reasons to state that modernization processes pursue new requirements to professional training of students, and hence to the managing activity of the heads of educational institutions. In this context, it should be noted that the development of education depends substantially on innovative management which is characterized by achieving a new level of quality of professional training of university students.

The issue of continuous improvement of professional activity performed by the head of an educational institution as an expert capable of implementing innovative techniques when teaching future tutors' is considered to be important and relevant in this context. Therefore, the professional training of tutors should be aimed at implementing the principle of individualization in education. It should be noted that this principle is one of the main ones in the open education system that is being formed. O. Marmaza states that, according to statistics, only $12 \%$ of educational institutions leaders outline the strategic plans of management with innovations in the educational process. Thus, a paradoxical situation appears: "Work for work - everyone is implementing something, but the results are not very comforting" [2, p. 3]. Considering the realities of today, there are new conditions that contribute to the development of new approaches in the management of innovative processes of tutors' professional training in the higher education system of Ukraine.

An important contribution to the study of new understanding of the reforms in education has been made by an innovation management expert M. Fullan who interprets the essence of educational changes as follows: "On the one hand, it is necessary to maintain the values, aims and consequences of certain changes in education, on the other hand, it is necessary to understand the dynamics of educational changes as that of a social and political process that includes all kinds of factors working in interaction with each other: from the level of the individual, regional and national levels. The issue of sense is the issue of how those involved in the process of changes begin to understand what to change and what is the best way to do it knowing that the "what" and "how" constantly interact and provide each other with a new meaning. Decisions are made through a joint production of sense. The interaction between the individual and collective sense and action in everyday situations is where it is decided whether the changes shall occur or not" [8, p.15].

M. Fullan proposed eight key lessons of the new paradigm in education that are implemented by almost all of the heads of higher educational institutions: one need not manage important processes (the more complex the change is, the less we can affect it); the change is a journey rather than a separate scheme (the change is nonlinear, overloaded with uncertainty and enthusiasm, and sometimes it is unbearable); problems are our friends (no one can avoid problems, and we cannot learn without them); vision and strategic planning will come later; individualism and collectivism have to be of the same effect; neither centralization nor decentralization can act alone; relationship with the wider environment is mandatory for success (best organizations learn from the outside as well as inside); everyone is the bearer of changes [8].

Under the modern conditions of the education development in Ukraine it is a priority to develop the new content, methods of training the tutors who need not only knowledge but also specific skills in innovation activities $[3 ; 5 ; 7]$. At this, interactive training significantly stimulates cognitive activity of future tutors and promotes the formation of subject and general educational competencies: mastering the stages of learning activities; improving 
critical thinking; increasing self-confidence; developing autonomy; strengthening positive "self-concept"; enhancing creativity; optimizing organizational and communication skills; forming life and professional competences; creating an atmosphere of cooperation and effective interaction; improving the academic performance. Tutors' training aims to reach the educational outcomes that meet the requirements of the modern society. Tutors should concentrate their efforts on the formulated aim, distinguish the primary and the secondary things, find likeminded people, and organize teaching staff to perform innovative tasks. Thus, to develop tutors' research, creative and cognitive activity it is necessary to create special conditions at practical classes. One of the effective ways to solve this problem is introduction of interactive learning - a special form of cognitive activity that has a specific purpose - to create a comfortable learning environment where everyone feels his/her success and intellectual ability. Innovative interactive technologies make it possible to develop analytical thinking, the ability to anticipate, generate tutor skills.

The scientific literature review gives us a reason to assert that while choosing methods of tutors' training teachers of higher educational institutions have to analyze the content of educational material and apply active methods where creative thinking of the future tutors may be particularly effective. Using innovative educational technologies of tutors' training in combination with thorough knowledge of the subject makes it possible to develop the educational situation systematically. Interactive tutors' training should not be episodic (today the teacher introduces interactive teaching methods, and tomorrow he/she uses the traditional teaching methods again).

The analysis of pedagogical works shows that today a modern teacher should use active teaching forms and methods: problem lectures, problem seminars, case discussions, round table, scientific-practical conferences, educational problems, game simulation; didactic games, trainings. In line with our issues concerning the study of specific features of tutors' training, special attention should be paid to the method of portfolio. It is traditionally believed that the method of portfolio is designed to systematize the experience gained by an expert, his/her knowledge, of a more specific direction of development, of simplified advice from qualified psychologists and administration. It helps to evaluate the expert's professional level more objectively.

The implementation of the method of portfolio in the course of tutors' professional training involves constant updating of professional knowledge and skills. Within the programs of tutors' training the portfolio method is used in assessing their readiness for work and also in course of career growth. Thus, the method of portfolio is a powerful means which can help to characterize academic and professional experience of an expert.

As a result of the comprehensive analysis of the philosophical, sociological, educational, psychological literature on the issue of tutors' professional training, there has been singled out a number of inconsistencies that negatively affect the results of the educational process, in particular between: government and public requirements to the degree of tutors' innovation competence and the existing level of training to perform innovation activities; established traditions of tutors' training and modern understanding of innovative educational technologies; urgent need for tutors' professional training and lack of proper study of scientific and methodological principles in education; motivated need for scientifically substantiated intensive system of tutors' training and implemented extensive approaches in the educational process that demonstrate lack of quality indicators of tutors' professional training to prepare them for innovative activities.

The issue of tutors' training to prepare them for innovative activity is relevant in regard to the necessity of implementing the Order of the Ministry of Education and Science of Ukraine dated November, 7, 2000, No. 522 "Regulation on the Procedure of Innovative Educational Activity" [4]. Despite the fact that higher educational institutions have the need to train tutors, many of them do not have curricula for tutors' professional training. Most tutors carry out their responsibilities, guided by intuition. The overcoming of the described contradiction is possible through the training of tutors by means of innovative pedagogical technologies that contribute to the creation of a system of their ongoing professional realization of personal potential. Tutors' professional training should take into account the current socio-economic context of professional branch, as well as the need for the new professional functions for tutors' performance.

The overcoming of the identified contradictions requires a thorough analysis, working out and grounding scientific and methodological foundations of tutors' professional training by means of innovative technologies in higher educational institutions of the $3^{\text {rd }}-4^{\text {th }}$ levels of accreditation.

The literature review on the topic also shows that tutors, tutorants (pupils, students) are considered to be ordering customers of their own individual educational trajectory, higher educational institutions, secondary schools, social services, enterprises, local communities. For this purpose the following steps are taken: the methodical councils of higher educational institutions on implementation of curricula for tutors' professional training, summer schools for tutors' training, research laboratories and centers that develop and adopt curricula for tutors' professional training, centers of educational and scientific expertise are created $[1 ; 6]$.

The individualization of educational curriculum is provided through tutorants' individual selection of the profile of learning, curricula, core and optional courses, various innovative forms of education, self-determination of topics and areas of research and creative activity. This choice is made by tutorants as individual educational trajectory, which is created on the basis of the research available educational resources of educational institutions of the city, the region, the Internet. The main condition of the educational process individualization is the openness and flexibility of the curricula from the system of tutorial 
support. It is important, in particular, to create such learning environment, interacting in which future tutors will be able to form competence, readiness for innovative professional activity (individual psychological qualities of a personality, motives of activity, knowledge, practical skills) that will ensure the effectiveness and quality of implementation of new areas of activity.

In terms of the deployment of cultural-educational space professional training of tutors involves the implementation of a system of specific principles, which are logically interconnected with general pedagogical ones, namely: the principles of historicism; objectivity; systematic approach; development; complexity; focus on the development of emotional and value sphere of the tutor's personality; focus on the development of activity-practical sphere of the tutor's personality; the feasibility of a combination of forms, methods and means of teaching; diversity; social orientation; continuity; interdisciplinarity; integration; the provision of effective conditions for the fulfillment of personality oriented objectives of tutors' professional training.

Therefore, the expected result of tutors' professional training by means of innovative teaching technologies is a high level of tutors' preparedness for implementing innovative pedagogical activities. In general, the procedural training of tutors by means of innovative pedagogical technologies will make it possible to process creating models of individual educational trajectories, criteria of effectiveness of thinking processes and operational activity.

The scientific-methodological context of tutors' professional training is based on the conceptual issues of the UN Convention "On the Rights of the Child", World Declaration "On the Survival, Protection and Development of Children", World Declaration and Action Plan "The World fit for children", laws of Ukraine "On Education", "On Higher Education", "On General Secondary Education", “On Preschool Education”, "On Extracurricular Education", "On Scientific and Scientific-Technical Activities", "On Priority Directions of Innovation Activity in Ukraine", Regulation on the Procedure of Innovative Educational Activities, registered in Ministry of Justice of Ukraine dated December, 18, 2012 No. 2111/22423, Regulation on the Experimental Comprehensive Educational Institution (as amended by the order of MES of Ukraine dated November, 23, 2009, No. 1054).

With the aim of implementing the Concept of scientific-pedagogical project "Tutor School of Excellence", carrying out fundamental and applied research on the problem of professional tutor support, effective use of the creative potential of scientific and pedagogical staff of the departments in scientific research on the issue of tutor skills and implementing the order of the Ministry of Education and Science of Ukraine dated June, 30, 2016 No. 730 "On Holding the All-Ukrainian Experiment on Implementation of Scientific-Pedagogical Project "Tutor School of Excellence", the experimental work has been carried out on the basis of Melitopol Bohdan Khmelnytskyi State Pedagogical University. The Centre of Tutor
Excellence of Melitopol Bohdan Khmelnytskyi State Pedagogical University was established by the decision of the university academic council. It performs the following duties: develops fundamental and applied researches; delivers professionally-oriented educational services and tutor activities for the graduates of "Tutor School of Excellence"; facilitates tutors' training and involves higher education applicants into research work; develops and approves individual educational programs on implementing tutor practices, etc.

University and school teachers will be trained and retrained to implement tutor activity and become tutors in case if: they master innovative teaching techniques and methods of creativity activization, creativity and independence of students' thinking; the content of the training is innovationoriented; they are competent and ready to discuss upgrading and novice of tutors' training; they present individual projects of supporting the coordination of all diverse structures, the aim of which is to encourage students to make conscious career choices and to make decisions, strategically important for life; they have knowledge and practical skills for scientific and educational expertise in self-awareness and designing their own image; have high theoretical knowledge and practical skills in the basics of tutor support; have a professional identity that ensures the integrity of motivationaltargeted, cognitive, operational-acting and reflectiveevaluative components of future tutors' readiness for innovative professional activity. One of the conditions of the development of scientific-pedagogical project "Tutor School of Excellence" is research activities carried out by educational process participants, which is realized at scientific and practical seminars, in scientific consultations and independent scientific work in educational and scientific programs.

According to the plan of research work of scientificpedagogical project "Tutor School of Excellence" on the basis of Melitopol Bohdan Khmelnytskyi State Pedagogical University the diagnostics of scientific and pedagogical staff readiness for innovation was carried out. The research work was organized in accordance with the basic requirements to the pedagogical experiment performance (Yu. Babanskyi, S. Honcharenko, N. Kuzmina, V. Slastionin, etc.). 186 people participated in the study who were divided into two experimental groups (EG 1.1 and EG 1.2) and two control groups (CG 1.1 and $C G$ 1.2). The research work consisted of three stages: explorativetheoretical, experimental, and consolidating. In order to determine the readiness for innovative activity of the teaching staff the questionnaires and diagnostic techniques "The methods of determining the teacher's ability to self-development" (by I. Dychkivska), "The map of pedagogical evaluation (self-evaluation) of teacher's ability to innovate activity" (O. Marmaza) were used.

The analysis of the cards for diagnosing the level of readiness of scientific and pedagogical staff for innovations has shown that the selective average indicator of the teaching staff is $56 \%$, which corresponds to the average level of readiness for innovations. So, there is a focus on the creation of organizational-pedagogical conditions of 
scientific-pedagogical staff professional training for the implementation of tutor activity, the positive dynamics of which will be confirmed by the formation of a motivational-targeted component; qualitative indicators of the formation of a cognitive component; qualitative indicators of the development of operational-acting component; positive indicators of the formation of reflectiveevaluative component.

The results of the research proved that the system of tutors' training should involve three interconnected blocks: the target, content-operational and resulting ones. The target block includes the aim and objectives; the content-operational block includes principles, content, organizational-pedagogical grounds, forms and methods of tutors' training; the resulting block includes indicators and the result. Professional training of tutors is a multi- faceted process which involves the mastery of the basics of innovative educational activity and ensures the implementation of innovative professional activity by tutors.

According to the results of the assessment of the levels of scientific and pedagogical staff's readiness to the implementation of innovations during the formative stage of the pedagogical experiment the data on the positive dynamics in the experimental and control groups of participants were obtained (Table 1). Thus, the analysis of the results of the formative experiment has shown that in experimental groups, where the purposeful professional training of pedagogues for tutor activity was delivered, the overall index of the level of readiness for this type of activity increased from low $(59.2 \%)$ to high $(52.4 \%)$. In the control groups it has increased from low $(62.9 \%)$ to medium $(50.7 \%)$

Table 1.

The level of readiness of scientific and pedagogical staff for tutor activity $E G$ and $C G$ at the beginning and at the end of the experiment

\begin{tabular}{|c|c|c|c|c|}
\hline \multirow{2}{*}{ Levels (in \%) } & \multicolumn{4}{|c|}{ Scientific and pedagogical staff } \\
\cline { 2 - 5 } & \multicolumn{2}{|c|}{ Before the experiment } & \multicolumn{2}{c|}{ After the experiment } \\
\cline { 2 - 5 } & EG & $\begin{array}{c}\text { CG } \\
\text { EG }\end{array}$ & $\begin{array}{c}\text { CG } \\
96 \text { persons }\end{array}$ \\
\hline High & 96 persons & 90 persons & 52,4 & 17,3 \\
\hline Medium & 28,1 & 10,6 & 36,1 & 50,7 \\
\hline Low & 59,2 & 62,9 & 11,5 & 32 \\
\hline
\end{tabular}

Statistically significant difference of ratios of the experimental and control groups before and after the formative stage of the experimental work convincingly proves the expediency of implementation of all developed scientific and methodological principles into the process of training and retraining of scientific and pedagogical staff.

The pedagogical experience shows that the scientific-pedagogical grounds of tutors' professional training are the factors that optimize cognitive activity, creative thinking and professional focus. These grounds must be implemented on the principles of integrity - mutual influence, mutual development and mutual complementarity of the system components. From this perspective, the compliance with one of the conditions cannot fully ensure the effectiveness of tutors' training. But their integrity gives the opportunity to achieve good results and creates the complex of scientifically-methodical grounds for forming tutors' readiness to innovative professional activities. Socio-legal protection of persons, undergoing professional training and retraining of tutors, is provided by the state authorities and institutions of Ukraine according to the law.

\section{REFERENCES}

1. Lytvynenko, T. A. (2012). Indyvidualizatsiia v osvitnomu protsesi: shliakhy tiutorskoi dopomohy $\mathrm{v}$ pryvatnykh navchalnykh zakladakh [Individualization in the educational process: ways of tutor support in private educational institutions]. Humanitarnyi visnyk ZDIA - Humanitarian Newsletter ZSIA, 50, 165-172 [in Ukrainian].

\section{Conclusions}

In terms of higher education modernization in Ukraine, the creation of conditions for the organization of the innovation process is essential. This requires the training of tutors who will acquire the skills of facilitation and tutor excellence. Thus, in the process of transition of educational institutions into a new qualitative state of functioning, the leading role belongs to the development and implementation of pedagogical innovations, by efforts of professionally competent, psychologically wellprepared, creative teaching staff in collaboration with scientists. Moreover, this process of practice and theory interconnection in pedagogy is inseparable.

Further research studies will involve the issue of the development and justification of the theoretical model of tutor activity in the system of national education; the development of tutors' training programmes; carrying out systematic diagnostics of learning motivation, selfevaluation of reflection levels, creativity and overall creative development of tutors; the development of a complex monitoring of all directions of scientific-pedagogical project "Tutor School of Excellence".

2. Marmaza, O. I. (2006). Stratehichne upravlinnia: traiektoriia uspikhu [Strategic management: trajectory of success]. Kharkiv: Osnova [in Ukrainian].

3. Modernization of education in Ukraine. Analytic review of results of all-Ukrainian inquiry of comprehensive school headmasters in 2004 (10 th ed.). (2004). Kyiv: K.I.C. 
4. Nakaz Ministerstva osvity $i$ nauky Ukrainy vid 07.11.2000 r. № 522 «Polozhennia pro poriadok zdiisnennia innovatsiinoi osvitnoi diialnosti» [Order of the Ministry of Education and Science of Ukraine of 07.11.2000, No. 522 «Regulation on the Procedure of Innovative Educational Activity»]. (n.d.). Retrieved from: http://zakon4.rada.gov.ua/laws/show/z0946-00 [in Ukrainian].

5. Pavliutenkov, Ye. M. (2011). Mystetstvo upravlinnia shkoloiu [The art of school management]. Kharkiv: Osnova [in Ukrainian].

6. Pakhomova, T. (2012). Shliakhy vprovadzhennia tiutorskoi systemy osvity u zarubizhnykh krainakh [The ways of implementing tutor system of education in for-

\section{ЛІТЕРАТУРА}

1. Литвиненко Т. А. Індивідуалізація в освітньому процесі: шляхи тьюторської допомоги в приватних навчальних закладах / Т. А. Литвиненко // Гуманітарний вісник ЗДІА. - 2012. - № 50. - С. 165-172.

2. Мармаза О. І. Стратегічне управління: траєкторія успіху / О. I. Мармаза. - Х. : Основа, 2006. - 160 с.

3. Модернізація освіти в Україні. Аналітичний огляд результатів всеукраїнського опитування керівників загальноосвітніх навчальних закладів у 2004 p. - K. : «K.I.C.», 2004. - 32 c.

4. Наказ Міністерства освіти і науки України від 07.11.2000 p. № 522 «Положення про порядок здійснення інноваційної освітньої діяльності» [Електронний ресурс]. - Режим доступу : http://zakon4.rada.gov.ua/laws/show/z0946-00. eign countries]. Problemy pidhotovky suchasnoho vchytelia - Problems of modern teacher's training, 5(P. 1), 220-224 [in Ukrainian].

7. Ukaz Prezydenta Ukrainy vid 17.04.2002 r. № 347 / 2002 «Pro Natsionalnu doktrynu rozvytku osvity» [Ukraine Presidential Decree of 17.04.2002 No. 347 / 2002 «On National Doctrine of education development»]. (n.d.). Retrieved from: http://zakon4.rada.gov.ua/laws/show/347/2002 [in Ukrainian].

8. Fullan, M. (2000). Syly zmin: vymiriuvannia hlybyny osvitnikh reform [Changes forces: measuring the depth of educational reforms]. Lviv: Litopys [in Ukrainian].

5. Павлютенков Є. М. Мистецтво управління школою / С. М. Павлютенков. - Х. : Основа, 2011. - 320 с.

6. Пахомова Т. Шляхи впровадження тьюторської системи освіти у зарубіжних країнах / T. Пахомова // Проблеми підготовки сучасного вчителя. - 2012. - № 5 (Ч. 1). - С. 220-224.

7. Указ Президента України від 17.04.2002 p. № 347 / 2002 «Про Національну доктрину розвитку освіти» [Електронний ресурс]. - Режим доступу : http://zakon4.rada.gov.ua/laws/show/347/2002

8. Фуллан М. Сили змін: вимірювання глибини освітніх реформ / М. Фуллан. - Львів : Літопис, 2000. $-269 \mathrm{c}$.

Анатолій Миколайович Солоненко,
доктор біологічних наук, доцент кафедри ботаніки і садово-паркового господарства, ректор Мелітопольсько-
го державного педагогічного університету імені Богдана Хмельницького,
вул. Гетьманська, 20, м. Мелітополь, Україна,

Ольга Володимирівна Познанська,

начальник відділу з питань спеціальної перевірки та очищення влади департаменту кадрового забезпечення Міністерства освіти і науки України, пр. Перемоги, 10, м. Київ, Украӥна,

Юлія Іванівна Попелешко, кандидат педагогічних наук, старший викладач кафедри педагогіки та педагогічної майстерності, Мелітопольський державний педагогічний університет імені Богдана Хмельницького, вул. Гетьманська, 20, м. Мелітополь, Украӥна

\section{НАУКОВО-МЕТОДИЧНИЙ КОНТЕКСТ ПРОБЛЕМИ ФАХОВОЇ ПІДГОТОВКИ ТЬЮТОРІВ У СИСТЕМІ ВИЩОЇ ОСВІТИ УКРАЇНИ}

На сучасному етапі розвитку вітчизняної освіти пріоритетним завданням стає досягнення якісно нового рівня підготовки тьюторів, що демонструють здатність до безперервної самоосвіти й самовдосконалення у сфері професійної діяльності. Практична ефективність тьюторської діяльності залежить насамперед від готовності педагогів впровадити іï на організаційному та науково-методичному рівнях. Одним із проявів тьюторської майстерності $\epsilon$ перехід на вищий рівень суспільного розвитку з орієнтацією на інноваційний потенціал науково-педагогічних працівників. Мета статті - визначити науково-методичний контекст проблеми фахової підготовки тьюторів у системі вищої освіти України. Для реалізації мети використано комплекс сучасних загальнонаукових методів: теоретичні методи - аналіз (історичний, порівняльний), синтез, узагальнення, зіставлення, що послугували вивченню літературних джерел, законодавчої й нормативно-правової бази, досвіду фахової підготовки тьюторів; емпіричні методи обсерваційні (пряме й непряме спостереження, методи експертного оцінювання та самооцінювання); ранжування; діагностичні (анкетування, експертне опитування, бесіди), що допомогли з'ясувати рівень сформованої готовності науково-педагогічних працівників до тьюторської діяльності; методи експериментально-теоретичного рівня - експе- 
риментальна перевірка ефективності науково-методичних засад фахової підготовки тьюторів у системі вищої освіти України; методи математичної статистики, застосовані для опрацювання отриманих даних і вивчення кількісних залежностей між аналізованими явищами і процесами. Результати формувального етапу експерименту засвідчили ефективність організаційно-педагогічних умов готовності науково-педагогічних працівників до тьюторської діяльності. Одержані кількісні дані наприкінці формувального етапу в порівняльному аспекті з кількісними показниками констатувального етапу дослідження дали змогу зафіксувати позитивну динаміку: в експериментальних групах слухачів узагальнений показник рівня готовності до названого виду діяльності зріс із низького до високого; у контрольних групах - із низького до середнього. Отже, кількісний та якісний аналіз результатів експериментальної роботи підтвердили доцільність впровадження запропонованої системи заходів професійної підготовки тьюторів.

Ключові слова: тьютор, тьюторська діяльність, педагогічні інновації, підготовка, компетентність.

Submitted on April, 6, 2017

UDC: 373.1

DOI: https://doi.org/10.24195/2414-4665-2017-4-27

Olena Vasylenko,

PhD (Candidate of Pedagogical Sciences), associate professor, Department of Psychology and Pedagogy,

Alla Sheremet,

PhD (Candidate of Pedagogical Sciences), senior teacher, Department of Social Work and Social Pedagogy,

Khmelnytsky National University,

11, Instytutska Str., Khmelnytskyi, Ukraine

\section{PECULIARITIES OF CAREER SELF-DETERMINATION OF MODERN HIGH SCHOOL STUDENTS}

The issue of career self-determination of modern high school students is highly crucial at present when labour market is constantly developing thus increasing requirements for modern specialists training. Some young people do not have clear perspectives on life and feel insecure, unconfident. Other high school students choose careers which are of no demand at enterprises and that is why they work in the specialty they have no qualification for. The paper aims to study motives and factors influencing the process of career self-determination of modern high school students and specify effective methods of cultivating students' conscious attitude towards making a future career choice. The school students were asked to do a survey using the questionnaire designed by authors. Besides, the respondents' personal ability to make a career choice was determined using techniques "What do I like?" (by L. Jovaiša) and "Career Map" by Ye. Klimov. The received results enable us to find out positive and negative factors which affect the process of career self-determination of modern high school students and to study what motivates students when they make their career choices. Basing on the research results it can be concluded that the most effective methods to cultivate career self-determination in high school students are trainings in particular the one called "Life map: to make one's own career choice".

Keywords: career, career self-determination, high school students, motives and factors of career selfdetermination, methods of cultivating one's career self-determination.

\section{Introduction}

The issue of career self-determination of high school students has always been interesting for leading scientists and practitioners as this issue covers the decisive moment in the life of every person. This issue is highly crucial for early adolescence period as at this age young people's central mental new formation is focused on their future which determines their general perspective on life, appreciating themselves as part of a society, their awareness of being adults and at last outlining their purposes in life.

The obstacles which modern young people challenge on their way to self-determination are mostly associated with current problems such as the period of social and economic changes in our country when neither parents nor school are able to help them make their career choice. That is why a great number of school leavers choose prestigious jobs of a lawyer, an economist, a journalist, a manager, etc. Very few want to choose a career in the sphere of material production, social service, etc. Another problem is that an unsuccessful career choice that is without taking into account personal abilities and possibilities can result in a young person's losing perspectives on life and in some cases can lead to social maladjustment [2]. 